\title{
Gendered Guise: Shakespeare's use of Transvestism and Gender Appropriation in his Plays
}

\section{Sanghita Sanyal}

Assistant Professor, Departments of English and B.Ed., Loreto College, Kolkata, West Bengal, India.

Mail Id: sanghita.mail@gmail.com | ORCID ID: 0000-0002-2345-5951

\begin{abstract}
Often, transvestism or cross-dressing, (that is, wearing normative, gender-designated attire of the opposite sex) is both a leitmotif and a theatrical device in William Shakespeare's plays. It not only serves as an integral element of a narrative/plot but it is also a dramatic device that is applied in order to preclude the woman as an actor (vis-a-vis her accepted participation) in the plays. Naturally therefore, transvestism or using socially-determined attires open up newer discourses on cultural and gender stereotypes in Shakespeare's performative art, when crossdressing was a somewhat compulsive alternative abiding the social mores of that time, which did not quite expect women's active participation on-stage. In this paper we shall read how this gender imbalance on Shakespearean stage made the dramatis personae and the crew more significant, on the basis of their attires, cross-dressing and gender-appropriation on stage. We shall specifically read how the master playwright used cross-dressing also as a theme in his various plays which in a way problematized gender appropriation further.
\end{abstract}

Keywords: Transvestism, Cross-dressing, Gender, Gender Appropriation, Alternative Sexuality

\section{Disguise as a recurrent aspect in Shakespeare's plays}

According to Lee Jamieson in her essay "Disguise in Shakespeare", disguise is a powerful tool in Elizabethan England. One can instantly change one's position, alter an onlooker's perception on and off the stage. Despite the English Sumptuary Laws, (which could dictate what color and type of clothing individuals were permitted to wear, that can easily identify rank and privilege) disguise proved to be extremely convenient even for the audience: women would often be seen using some ways of 'identity covers-up' to go to the theatres. Importantly, characters resorting to disguise in a plot-device common in William Shakespeare's time. It was also considered "controversial and 
dangerous" (Jamieson, 2019). Simply put, disguise as assuming a different persona for the sake of some ulterior interest or motif, on stage, goes back to the Classical dramatic conventions and would supply as dramatic irony, when the audience might be aware of the reality while the characters are not. In Shakespeare's plays like King Lear, we find we find an excess of disguise, for that matter, to emphasize the theme of deception - Kent disguises as Caius, Edgar disguises as Poor Tom or even Goneril and Regan can also be said to hide their actual intentions, for which they do not have to assume any physical disguise but wins over Lear with their glib flattery. Jamieson even mentions masque balls also (as in Romeo and Juliet, A Midsummer's Night's Dream and Henry VIII) to substantiate this discourse as it would allow "people to behave differently to how they may do in everyday life. They could get away with more merriment and no one would be sure of their true identity" (Jamieson, 2019). In a way 'disguise' is seen as a common dramatic leitmotif that can infuse humour or even act as a crucial reagent to the plot. However, at this point, we veer our attention to the most problematic kind of disguise that can be seen in Shakespeare's plays transvestism or cross-dressing.

Transvestism or Cross-dressing, (that is, wearing normative, gender-designated attire of the opposite sex) is both a leitmotif and a theatrical device in Shakespeare's plays that create a recurrent discourse within Shakespeare scholarship. It not only serves as an integral element of a narrative/plot but it is also a dramatic device that is applied in order to include, exclude and negotiate with the woman as a character as well as an actor (vis-a-vis her accepted participation) in the plays. Naturally therefore, transvestism or using socially-determined attires open up newer discourses on cultural and gender stereotypes in Shakespeare's performative art, when we know that cross-dressing was a somewhat compulsive alternative or solution, abiding the social mores of that time, which did not quite expect women's active participation on-stage. According to Lucas Garcia's article "Gender on Shakespeare's Stage: A Brief History", although there were evidences of women participating in plays as in street performances et al,

All commercial acting companies of the time were made up entirely of men and it was illegal for women to act on stage professionally until 1661. Despite the profession of acting having a less than virtuous reputation, as well as a growing orthodox Christian objection to the theatre, these all-male companies were deemed as socially legitimate because they did not threaten gender hierarchy. (Garcia, 2018)

\section{Cross-dressing in Elizabethan Society and Shakespeare's Plays}

This gender imbalance on Shakespearean stage obviously made the dramatis personae and the crew more problematic- their attires, dialogues all would emphasize the ploy of cross-dressing and gender-appropriation on stage, and not only supply as the dramatic irony but also make an important statement about gender dynamics of the time, how gender, sex and sexuality were understood and what was women's position. In fact, the master playwright's use of cross-dressing and gender appropriation opened up a very intricate discourse on Gender on Shakespeare's stage. 
We see transvestism in Shakespeare's plays in two ways:

1. As a part of the narrative, as characters, women dressing up as men or men dressing up as women and fuelling and driving the rising action and complications forward, in the plot.

2. As a part of the theatrical (social) convention, men dressing up as women on stage, since women performing in public theatres was not an accepted and approved practice in the cultural matrix.

Before going into a detailed discussion on these two aspects of transvestism, let me first give you a concrete set of information to grapple with. Michael Shapiro in the appendix of his book Gender in Play on the Shakespearean Stage: Boy Heroines and Female Pages counts 80 cross-dressed characters on the early-modern English professional stage, but it is impossible to determine the exact number. Of the 38 surviving plays attributed to Shakespeare, quite a few involves cross-dressed characters; however, just three of them are always talked about. They are, Portia in The Merchant of Venice (composed between 1596 and 1598), Rosalind in As You Like It composed in 1599 and Viola in Twelfth Night composed around 1601-1602.

Earlier than these, we find the heroines in The Two Gentlemen of Verona (composed between 1589 and 1593) disguising themselves as men, and also in Cymbeline (produced around 1611). Interestingly, in The Taming of the Shrew (written between 1590 and 1592) and in The Merry Wives of Windsor (written around 1597) male characters are disguised as women. We see Falstaff turning himself into The Fat Woman of Brentford and in The Taming of the Shrew we find Bartholomeo appearing as Madam. Additionally, as Phyllis Rackin points out, "three of Shakespeare's earliest history plays feature female characters who probably appeared in masculine battle-dress (Joan in Part I of Henry VI, Margaret in Part III, and Eleanor in King John)" (Rackin, 2019).

As literary historians, Renaissance and early modern scholars reflect and confirm, Shakespeare's time witnessed a very expectedly straightjacketed treatment of women, wrapped in androcentric values and conventions, following the Christian biblical values, although England had split from the English Church more than a century ago. The cultural practice was obviously misogynist and we find its direct repercussion on stage. Women could still be spectatorsin the audience, but certainly could not participate as actors on stage. Young boys and who would be regular actors on the professional stage would play all women's roles.

That justifies the dramaturgical need for cross-dressing. Young boys would dress up as females and perform the roles of women as a part of the narrative. Garcia records,

When a woman of this period transgressed gender boundaries and dressed in men's clothing in public, it associated her with the same social stigma that faced female actors, except that she was subject to arrest and imprisonment. One such woman was named Mary Frith, who was nicknamed Moll Cutpurse. Mary regularly went out in public dressed in men's clothing and was associated with London's criminal underground. She was also the subject of the 17th century play The Roaring Girl. Such behavior was understood as a threat to gender hierarchies of the time, and any woman apprehended "cross-dressing" was understood to be in rebellion against her betters, i.e. men. Any 
man caught in similar circumstances was also punished, as dressing in women's clothing was understood as a perversion of masculinity and a sign of moral and sexual degeneration. (Garcia, 2018)

Elizabethan diffidence towards transsexuality cannot be missed in this observation. Another Shakespearean critic, Farah Karim records in her article "Cross-dressing in Twelfth Night",

...in the early seventeenth century two pamphlets were published which spoke out furiously and anxiously against male and female cross-dressing: Haec-Vir and Hic Mulier, both published anonymously in 1615. The writers of these pamphlets argued that cross-dressing was 'monstrous', unnatural and made one look like they didn't belong to any one gender. (Karim, 2016)

However, although cross-dressing in public, was considered punishable at that time in England, theatre, however was an area where, manipulating gender-appropriation was in vogue, although by men, only.

This kind of Transvestism for the sake of dramaturgy could also lead to amusing complication as an obvious upshot, because a boy actor cross-dressed as female would play the role of a woman throughout the play and then if the woman character in the plot is further cross-dressing up as a man, then the boy is metaphorically playing the character, but literally dressing up as a man. That would catapult the boy actor to a very complicated position. As a male in reality, he is playing the role of a woman throughout and when the woman (within the play's plot) is disguising as a man, the boy is no more dressing up as a woman, but his dialogues would testify that he is a woman in masculine disguise. InAs You Like It, for instance, a boy actor pretends to be Rosalind throughout, and when Rosalind decides to disguise then this boy actor, despite his male reality, is still pretending to be a cross-dressed woman, that is Ganymede. This can also be for Portia, or Viola as well, when they are cross-dressing within the plot of the play.

Beyond the confusion, it brings us into the theme of transvestism within the plot. The women are mostly seen to be crossdressing as men and doing things which are otherwise forbidden or unapproved for the Deuxième Sexe or 'the second sex', as Simone de Beauvoir had put it in the title of her book The Second Sex where she ironically observed that women, from their position of inferiority, could only strive for the four virtues, obedience, chastity, silence and piety. It is to be noted, that every female character in Shakespeare's plays who cross-dresses at some point, is doing it for the same reason, as women in real life throughout history, would often do. They dressed as men to be more secured on the streets, to be able to travel alone, to get work and better wages, to speak freely, write and publish, even to fight wars. Restrictions put on women have mostly been on the basis of the social insecurities that women would be exposed to, in a male-dominated, patriarchal world. Perhaps, patriarchy was distrustful of its own men, which is why they thought perhaps restrictions could save women. As a result, women had to cross-dress primarily to safeguard themselves as well as to break free from restrictive ambits of life. For instance, Viola in Twelfth Night, as she is shipwrecked, and estranged from her brother Sebastian, has to take recourse to cross-dressing in order to save herself in an unknown land. She says, "Conceal me what I am..." 
(Shakespeare, 1980) and further, sustains herself as a page to Duke Orsino. Similarly, Portia in The Merchant of Venice disguises herself as Lawyer Balthazar to be able to save Antonio at the court. She has to cross-dress because women were restricted from a lawyer's profession in Elizabethan times. Even in As You Like It, we find Rosalind to dress up as a man in order to stay safe in the forest of Arden and she can speak more comfortably and casually with Orlando, which otherwise would have been difficult as a woman.

Therefore, as a corollary, it was presumed that women who are apparently bold and having a 'loose' life can dare to step into the male-domain of having a taste of outdoor life in a man's disguise. This was considered to be a transgressive idea by the conservatives of the time and heavily criticized. On a side line, let us also remember,

Between 1610 and 1620 there was a controversy over gender roles in England, leading to a pamphlet entitled Hic Mulier (This manlike woman). Hic Mulier was published in 1620 in an England that condemned transvestism. Women wearing men's clothes were becoming increasingly common, causing concern to social conservatives. The pamphlet argued that transvestitism was an affront to nature, The Bible, and society. As with the London aldermen and magistrates, the author of Hic Mulier associates female cross-dressing with sexual wantonness. (Karim, 2016)

\section{Reading the aftermath of Cross-dressing on stage}

Boy actors playing the role of women in the comedies was a part of practical feasibility, but beyond that, it cannot be overlooked that the playwright is exploring a problematic and disturbing space when he allows the public to imagine that women characters in his plays (and in society) are doing things which they are not supposed to. In Renaissance England, dress was the code of one's identity, symbolizing one's gender and social class. The stability of the social order depended much on maintaining absolute distinctions between male and female. If a woman put on men's clothes, she transgressed the gender boundary, and encroached on the privileges of the advanced sex. Renaissance gender stereotypes required women to wear women's clothes, to be submissive, passive, silent, closed off, and immured within home. However, in his plays, Shakespeare dresses his heroines in men's clothes, directly impinging upon the privileges of men, and rattles the gender stereotypes, being well grounded in conformation to the conventions. Perhaps Shakespeare treatment of transvestism within the plot is trying to create a fine balance with the changing views of women's position, following humanist ideology of freedom and the Elizabethan resolutions of patriarchy. This makes us raise a whole lot of questions:

What is Shakespeare's plausible agenda behind this endorsement? Although we find Shakespeare's treatment of the transsexual or transgender to be quite contentious, and gendered, the crossdressing women were rather common and perhaps a fuel to the burning glory of masculinity! Or was it an obverse? Was Shakespeare covertly trying to push up women's potential and participation in Elizabethan theatrical milieu of performative art and social life? Or was he using the 'female impersonator' as a ploy to bring back women each time back to their square one, to the ideological 
conditioning of inferiority where they supposed to belong to? Or, to push our surmises further, was Shakespeare trying to make cryptic attempt at signalling at the validity of the transsexual and the transgender in everyday life or go by the Christian biblical diktats? As Vita Fortunati observed in her essay "The 'Female Page': Transvestism and 'Ambiguity' in Elizabethan Theatre Roles" that, "the historical exclusion of women from the stage" can be attributed to two primary reasons: one, the theatre is conventionally considered a public arena and two, women were not considered "socio-historical subjects in their own right". Yet, when the theatre is also a space "in which the return of the repressed was brought to light and elaborated, it could not entirely refuse to talk about women." Now, could we draw this observation of Fortunati further and include the third gender question in it? Drawing from her, could we say that Shakespeare's cross-dressing theme was attempting to resolve a contradiction? - on one hand it denied women (and the third gender, obviously) a status to participate on stage, and on the other hand, was "unable to suppress the denial, indeed, it was obliged to represent it", (Fortunati, 1992) in a roundabout way, by validating it through the garb of the plot's requirement. As if, Shakespeare tries to dispel a normative heterosexual certitude with such deliberate incorporations.

We find in The Merchant of Venice Portia dresses herself as the young lawyer Balthazar and her maid as the clerk, and she conducts the court scene to save Antonio from Shylock. So, in order to travel to Venice unattended by a male companion and to enter the courtroom, Portia needs a man's disguised identity.

Next, Rosalind and Celia in As You Like It cross-dress themselves not just to pursue and test Orlando's love for Rosalind but also as a safety-measure when they are entering the forest of Arden. So does Viola in Twelfth Night. After the shipwreck when she arrives at Illyria without her brother Sebastian, she disguises herself as a young boy Cesario in order to survive alone and finds shelter as a page boy for the duke. In Two Gentlemen of Verona, Julia disguises herself in order to pursue her lover, outside the confinement of the home. So does Imogen in Cymbeline, when she visits her lover Leonatus.

There are two things running as a common strain: first, safety and free access to outdoor life, and second, pursuing love. If the first one puts a bit of pushback at women's vulnerable and precarious position in a patriarchal web outside home, the second one can be problematized even further. The women are adopting masculine alteration of social appearance (which is otherwise much censured) in order to secure and achieve something that is heteronormative and therefore, automatically accepted socially. Can we say, the female body is getting rejected by the real females and this is a strategy in order to underpin their hetero-normative femininity (that is supporting, saving and strengthening their love for the man). Is this not a kind of endorsing hyper-masculinity, in keeping with the times?

This sexual ambiguity can also be seen as moments when the playwright is conforming to stereotypes and affirms a social convention by negating it on stage. Here, we see, through crossdressing, Shakespeare is making women's frailty and stark womanly characteristics speak for their typecast weaknesses. 
For example, in Act 4 Scene 3 of As You Like it, when Oliver, Orlando's brother, shows her the napkin 'dy'd' in Orlando's blood and says: 'Be of good cheer, youth. You a man? You lack a man's heart' (4.3.162), Rosalind as Ganymede answers 'I should have been a woman by right' (Shakespeare, 1980) which serves as a sharp dramatic irony.

Another instance, in Twelfth Night Act 3 Scene 4, Viola is mortally scared when she is challenged to a duel with Sir Andrew Aguecheek, as she gasps: 'Pray God defend me! A little thing would make me tell them how much I lack of a man' $(3.4 .287,368)$.

On the other hand, Portia, tells Nerissa as she turns herself into Balthazar,

"When we are both accoutred like young men, I'll prove the prettier fellow of the two, and wear my dagger with the braver grace, And speak between the change of man and boy, With a reed voice, and turn two mincing steps Into a manly stride; and speak of frays Like a fine bragging youth, and tell quaint lies..." (The Merchant of Venice, 3.5.63-69, 242)

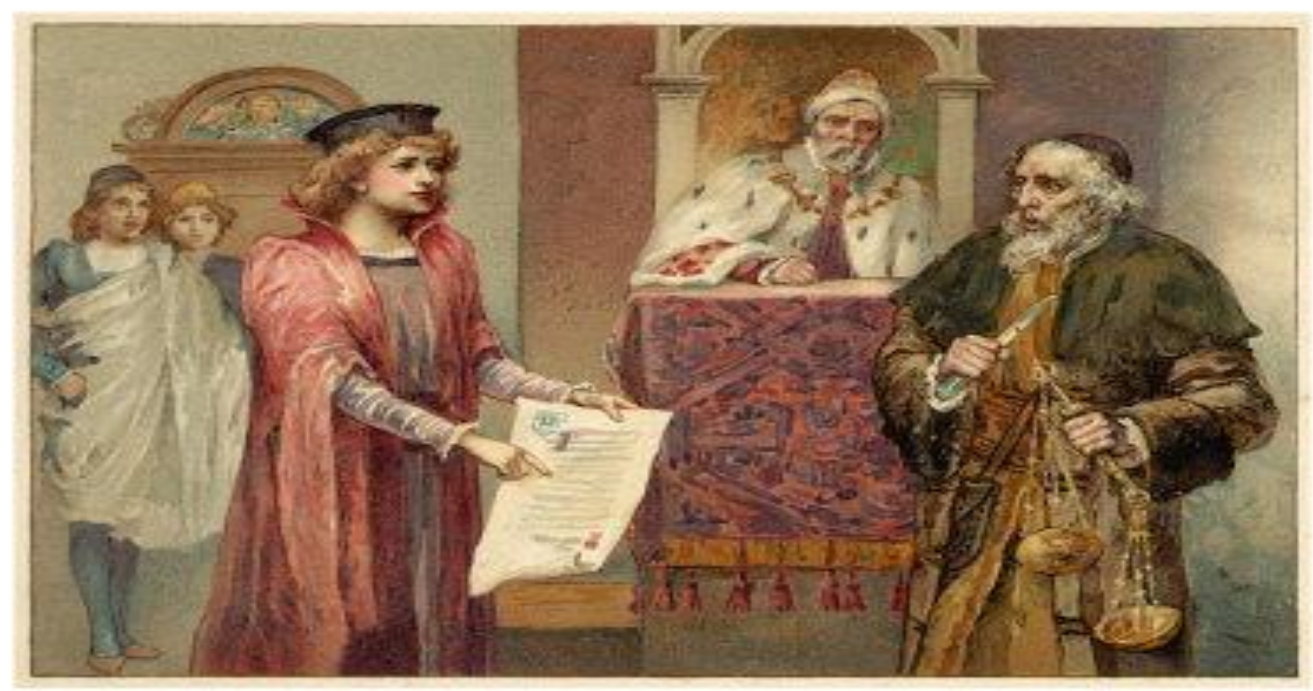

Image 1: The Merchant of Venice, Trial Scene ${ }^{1}$

This obviously stereotypes men's characteristics too, as does Rosalind's comment when she says,

"Were it not better, Because that I am more than common tall, That I did suit me all points like a man? A gallant curtle-axe upon my thigh, A boar-spear in my hand; and, ---- in my heart Lie there what hidden woman's fear there will, ---We'll have a swashing and a martial outside..." (소 You Like It 1.2.110-116, 260)

\footnotetext{
${ }^{1}$ Image 1: The Merchant of Venice, Act 4 Scene 1, Trial Scene <alamy.com> Web. April 202019
} 
Shakespeare also shakes our complacence further when we find Rosalind (as Ganymede) has a female admirer in Phoebe and Viola (as Cesario) sees Olivia feeling attracted more towards the page boy than the doting Duke Orsino.

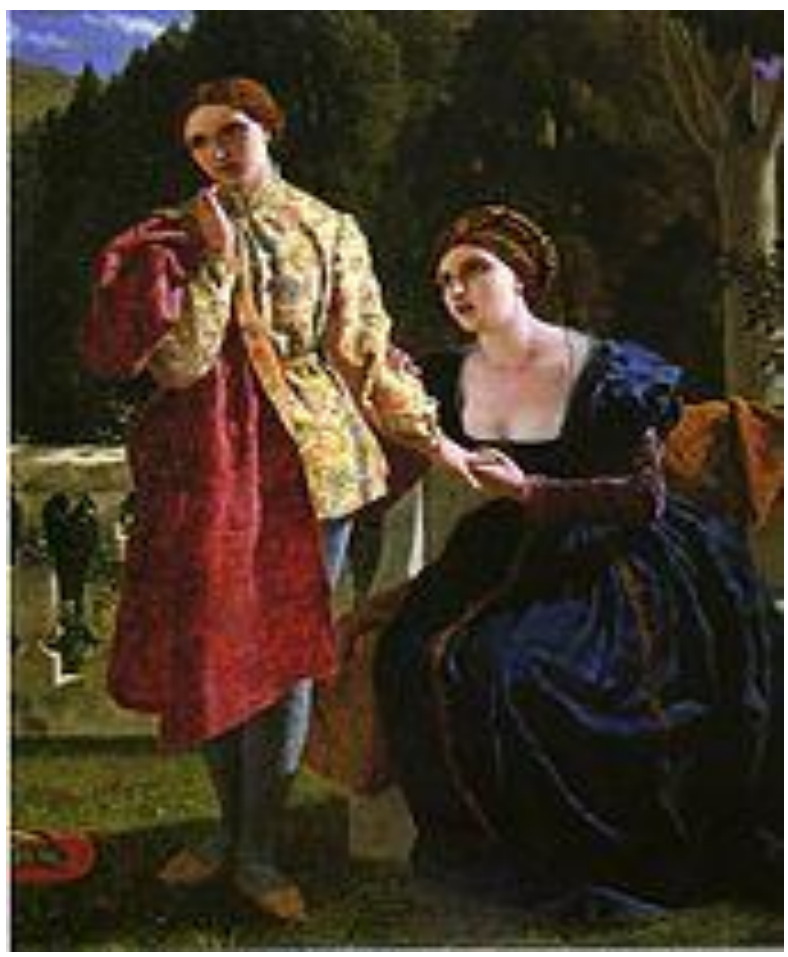

Image 2: Viola and the Countess²

In fact, as Lucie Johnová observes in her essay "Patterns of Crossdressing in Shakespeare's Comedies":

Viola seems to be the most feminine of the three. She crossdresses purely for safety and does not enjoy the part at all, she sees herself as a deformity. In her scruples and her femininity apparent even in the male disguise she is different from Portia and Rosalind. She needs a male authority of the seacaptain to be able to start her role. Moreover, her first plan is not to pretend to be a man but a eunuch, someone less masculine than a man. She obediently woos another woman for her beloved. She is alone with her secret, there is no female character with whom she could be Viola and not Cesario. Unlike Rosalind, she does not find amusing the fact that Olivia has fallen in love with her; she is troubled, because it further complicates her already difficult relationship with Orsino. Moreover, she genuinely pities Olivia, because she knows too well what an unrequited love feels like, she has the feminine quality of empathy... (罗hnová)

With such details to read more into the texts, we do see where Shakespeare is moving: perhaps towards a fine balance where women with all the virtues and gracefulness expected of them, are also displaying (in disguise) nonpareil strength to operate in a man's domain with visibly equal

${ }^{2}$ Image 2: Viola and the Countess, 1859. Painting by Frederick R. Pickersgill <English.emory.edu/classes> Web. April 202019. 
élan (and the silent trepidations in their heart only add to the dramatic effect of narrative and also keeping the audience at peace!) Shedding their womanly virtues for a few days, they successfully carry out their masculine self, displaying intelligence, wit, capability and courage. And we who are attempting a feminist reading, are left in a state of limbo thinking whether to magnify Shakespeare's subtle objective to finally bring the fictitious world back to balance, when the women go back to their selves, under their lover's power or to perceive the bard's use of transvestism as a subtle take on acknowledging women's potential that is equivalent to man, only physically 'different'; and that would anticipate 'equity' for the sexes in their social effectuality. So perhaps illusion of appearance works as the emancipation. Although it seems too good to be true, yet we wouldn't mind believing it!

\section{Conclusion}

Further, in the conclusion we must also remember what Miles Thompson and Imelda Whelehan believe, "as the theatre represents a space of metaphoric potential that can take advantage of the possibilities for disturbance and anarchy, so the stage provides a space for performances which include a homoerotic perspective." (Thompson, 2001). When popular scenes get overlayered by such contemporary interpretations around crossdressing, gender reversal and fluidity, then overt homoerotic speculations are obvious sprouts which tend to make that part of the text particularly subversive.

In Midsummer's Night's Dream, we do observe the homoerotic potential in the Helena-Hermia 'friendship' which is like a "union in partition" (Shakespeare, 1980). Also, when, induced by the love-juice, Hermia is reluctant to be with her lover, and instead prefers to be with Helena, it becomes all the more interesting because in the process of making the occasion jesting and playful, the love-juice makes the situation ironic, as the playwright can be claimed to be deliberately toying with the homoerotic idea running strongly despite the palpable heteronormative resolutions of the play. Even in As You Like It, we find instances where homoerotic subtexts are firmly established though they obviously reach no successful consequence. For instance, in As You Like It when Phoebe is attracted to Rosalind (dressed as Ganymede), her desire is normative because it is heterosexual, as Phoebe knows that Ganymede is a young gentleman. But the feature that Phoebe finds most attractive in Ganymede is her "complexion" which makes her a "pretty youth": "the best thing in him/ is his complexion" $(3.5 .112 / 115,274)$. This desire for the feminine beauty is made all the more interesting when Rosalind/Ganymede reciprocates to Phoebe's advances and says, "I think she means to tangle my eyes too!" $(3.5 .45,273)$, but most probably the Elizabethan audience would pass it as an authentic role-playing in a successful comedy.

Having discussed crossdressing and its impact on sexuality within and without the text, another point, can be raised contextually nonetheless, although it is slightly beyond the purview of this essay: that is, Antonio and Bassanio's relationship. In The Merchant of Venice, it is always Portia who 
is read most often as exploring a newer possibility by her disguise, what we cannot ignore is Antonio's very open and public declarations of fondness for Bassanio. Also, having no heterosexual romantic relationship to counteract Antonio's passionate sentiment and affection for his friend, his sexuality can be most obviously be conjectured to be homoerotic. On the other hand, as for Bassanio, although his love for Portia perceptibly makes him heterosexual, yet the possibility of his being bisexual cannot be completely ignored by contemporary scholars of Sexuality studies. Therefore, at the end, we may comfortably mark these observations as not just advanced portraitures and deeper interpretations triggered by the Renaissance conventions of crossdressing, but we are perhaps opening the vocabulary of Shakespeare's plays for more complex readings, in terms of semantics and pragmatics.

\section{References}

Cooper, Farah Karim. "Cross-Dressing in Twelfth Night." playingshakespeare.org. N.p., 2016. Web. 20 Jan. 2021 . <http://2016.playingshakespeare.org/sites/default/files/public/attachments/CrossDressing\%20in\%20Twelfth\%20Night.pdf>.

Fortunati, Vita. "The ‘Female Page': Transvestism And 'Ambiguity' In Elizabethan Theatre Roles." Proceedings Of The Conference Of The Spanish Society For English Renaissance Studies. S. G. Fernández. 1st ed. Spanish and Portuguese Society for English Renaissance Studies, 1992. 95-112. Web. 14 May 2021. <http://www.sederi.org/yearbook/sederi-2/>.

Garcia, Lucas. "Gender On Shakespeare's Stage: A Brief History." Writers Theatre. N.p., 2018. Web. 15 Apr. 2021 . <https://www.writerstheatre.org/blog/gender-shakespeares-stage-history/>.

Jamieson, Lee. "Disguise In Shakespeare." ThoughtCo. N.p., 2019. Web. 14 Mar. 2021. <https://www.thoughtco.com/disguise-in-shakespeare-2985303>.

Johnová, Lucie. "Patterns of Crossdressing in Shakespeare's Comedies". Prague: Charles University. <Microsoft Word - Pavel - komplet.doc (muni.cz)> Web. 20 April 2019.

Rackin, Phyllis. "Shakespeare'S Crossdressing Comedies". Cross-Dressing In Shakespeare'S Comedies - And Beyond." Finchpark.com. N.p., 2019. Web. 8 Feb. 2021. <http://www.finchpark.com/ppp/crossdressing/crossdressing-handout.pdf>.

Shakespeare, William. The Complete Works of William Shakespeare. New Delhi: Oxford Edition. 1980. Print.

Shapiro, Michael. Gender in Play on the Shakespearean Stage. Michigan: The University of Michigan Press. 1996. Print.

Thompson, Miles, and Whelehan Imelda. "Shakespeare And The Homoerotic." Talking Shakespeare: Shakespeare Into The Millennium. Deborah Cartnell and Michael Scott. London: Palgrave, 2001. Print. 
Sanghita Sanyal is teaching in the Departments of English and B.Ed., Loreto College, Kolkata. She is a doctoral research scholar in the Centre for Studies in Social Sciences, Calcutta (Kolkata). Gender and Sexuality Studies, Tagore Studies are her special areas of interest, besides Language and Translation Studies. 